\title{
Analysis of Demands for Farming Technologies and Appropriate Transfer Methods of Rice Farmers in Ibague, Tolima, Colombia
}

\section{Khoy, Rada}

Laboratory of Agricultural and Farm Management, Division of International Agricultural Resource Economics, Department of Agricultural and Resource Economics, Faculty of Agriculture, Kyushu University | Graduate School of Bioresource and Bioenvironmental Sciences

\section{Nanseki, Teruaki}

Laboratory of Agricultural and Farm Management, Division of International Agricultural Resource Economics, Department of Agricultural and Resource Economics, Faculty of Agriculture, Kyushu University : Professor

Chomei, Yosuke

Laboratory of Agricultural and Farm Management, Division of International Agricultural Resource Economics, Department of Agricultural and Resource Economics, Faculty of Agriculture, Kyushu University : Assistant Professor

\section{Blanco Ea, Ximena}

Laboratory of Agricultural and Farm Management, Division of International Agricultural Resource Economics, Department of Agricultural and Resource Economics, Faculty of Agriculture, Kyushu University | Fedearroz-National Federation Rice, Colombia

他

https://doi.org/10.5109/1801790

出版情報：九州大学大学院農学研究院紀要. 62 (1)，pp. 245-253，2017-02-24. Faculty of Agriculture, Kyushu University

バージョン：

権利関係 : 


\title{
Analysis of Demands for Farming Technologies and Appropriate Transfer Methods of Rice Farmers in Ibague, Tolima, Colombia
}

\author{
Rada KHOY ${ }^{1}$, Teruaki NANSEKI*, Yosuke CHOMEI, Ximena BLANCO² E.A., Winston MARTE ${ }^{3}$ \\ and Widya ALWARRITZI ${ }^{1}$
}

\begin{abstract}
Laboratory of Agricultural and Farm Management, Division of International Agricultural Resource Economics, Department of Agricultural and Resource Economics, Faculty of Agriculture, Kyushu University, 812-8581, Fukuoka, Japan
\end{abstract}

(Received October 17, 2016 and accepted November 4, 2016)

\begin{abstract}
Free Trade Agreement between Colombia and other countries in the region lead to remove the import duties to Colombia on the vast majority of agricultural products, particularly for rice. This would affect the rice price, and reduce rice farmers' income. Hence, Colombian rice farmers require improvement levels of efficiency to be competitive with the products from other countries. This study aims to determine the demands for farming technologies and appropriate transfer methods of rice farmers, and to identify the determinants of farmers' demands for those technologies. Ibague was selected to be the study area. Data was collected through face-to-face interview in April 2015. 105 rice farmers were interviewed, but only 70 respondents were included for analysis. Descriptive analysis was used to determine the demands for technologies and transferring methods. Then we adopted multivariate regression to identify the relationship between farmers' characteristics and component scores obtained from principal component amalysis (PCA). The results suggested that farmers require technologies that could help minimizing their cost and water issue. In particular, farmers showed high interest in sowing calibration, laser land leveling, soil analysis interpretation, fertilization planning, biological pest control, pest recognition and monitoring, and proper selection of the varieties. The results indicated farmers prefer field day for technology transfer once a month on Friday. They require prior notification of invitation by email and phone call between 3 to 7 days before the events. Farmers believed that social network and radio are the crucial tools to promote the technology transfer event. The results of multivariate regression suggested that farmers' preference of farming technologies is based upon their conditional characteristics and issues being faced. Hence, all technologies should be jointly innovated by the researchers and farmers.
\end{abstract}

Key words: Colombia, Demand of technologies, Rice farming, Transfer methods

\section{INTRODUCTION}

Rice, a staple food in Colombia, ranked $4^{\text {th }}$ in rice producer and $7^{\text {th }}$ in productivity $(4.9$ metric tones per hectare) in the Western Hemisphere (Durand-Morat, 2012). Production cost of rice farming in Colombia is substantially high compared to other countries in the region. However, highly protected market enables rice price to maintain at higher level than in the international market (Durand-Morat, 2012). The recent free trade agreements including MERCOSUR (Spanish: Mercado Común del Sur, English: Southern Common Market) and the United States-Colombia Trade Promotion Agreement (TPA) will impose major concerns to Colombian rice sector. These regional and bilateral free trade agreements will eliminate the barriers, particularly the import tariffs, on the vast majority of agricultural and processed products that imported to Colombia. The agreement between the US and Colombia, signed on 22 November 2006, and undertaken on 15 May 2012, also provides duty free tariff rate quotas (TRQ) on rice, which Colombia schedules to reduce tariff in period of 19 years with an initial amounts of 79,000 metric tones of

\footnotetext{
${ }^{1}$ Graduate School of Bioresource and Bioenvironmental Sciences, Kyushu University

2 Fedearroz-National Federation Rice, Colombia

${ }^{3}$ Ministry of Agriculture, Dominican Republic

* Corresponding author (E-mail: nanseki@agr.kyushu-u.ac.jp)
}

milled rice and 4.5\% annual increase. Garay et al. (2009) documented that Colombian rice cultivated area and production would drop 19\%, and rice price would decrease 20\% affected by TPA. This would affect Colombian farmers' income.

Colombian rice farmers require improved level of efficiency to be competitive with low cost and high quality of products from the US and region. To increase famers' efficiency, it requires solving farmers' production issues, and introducing a set of technologies that could respond to farmers' demand. The demand of farming technologies may be reflected from their concerns defined by the attributes. Farmers may view some attributes conversely, so the choice of farming technologies is greatly influenced by their preferences, resources, and constraints. A positive attribute for one farmer may be negative for other (Bellon, 2001).

Farmers will assess technologies based on a range of attributes that could meet their demand. To set the technology innovation, it is important to have the knowledge about the attributes demanded by farmers and their production system. This study, therefore, aims to determine the demands for farming technologies and appropriate transfer methods of rice farmers, and the determinants of farmers' demands for those technologies. 


\section{MATERIAL AND METHOD}

\section{Study site and data collection}

Ibague, the capital of Tolima, was selected to be study area. It is located at an altitude of 1,285 meter above sea level. Data was collected through face-toface interview using structured questionnaire in April 2015. Farmers were asked to select their preference on rice technologies regarding to calibration technology, irrigation, soil and fertilizer, pest management, and climate changes. The transferring methods were also included for farmers to choose from multiple possible answers. In total, 105 rice farmers in Ibague were randomly selected and interviewed, but only 70 respondents were included for analysis.

\section{Data analysis}

We used descriptive analysis to determine the demands for farming technologies and appropriate transfer methods of rice farmers.

To identify the determinants of farmers' demands for those technologies, we applied tetrachoric correlation for binary variable instead of Pearson correlation to obtain correlation matrix by referring to Edwards and Edwards (1984). Then Principal component analysis (PCA) proposed by Jackson (2003) was employed to reduce the dimensions of our variables (demand for technologies). Finally, we adopted multivariate regression to identify the relationship between farmers' characteristics and component scores obtained from PCA. Multivariate regression is specified as follow:

$$
\begin{gathered}
Y_{1}=\beta_{01}+\beta_{11} X_{1}+\cdots+\beta_{n 1} X_{n}+\varepsilon_{1} \\
Y_{2}=\beta_{02}+\beta_{12} X_{1}+\cdots+\beta_{n 2} X_{n}+\varepsilon_{2} \\
\vdots \\
Y_{p}=\beta_{0 p}+\beta_{1 p} X_{1}+\cdots+\beta_{n p} X_{n}+\varepsilon_{p}
\end{gathered}
$$

\begin{tabular}{|c|c|c|}
\hline Variables & Definition & Unit \\
\hline \multicolumn{3}{|c|}{ Rice farming technologies } \\
\hline \multirow[t]{7}{*}{ Calibration technology } & Desbrozadora & Binary \\
\hline & Dredge & Binary \\
\hline & Chisel & Binary \\
\hline & Land plane & Binary \\
\hline & Taipa & Binary \\
\hline & Laser leveler & Binary \\
\hline & Seeder & Binary \\
\hline \multirow[t]{5}{*}{ Irrigation } & Design irrigation & Binary \\
\hline & Frequency of irrigation & Binary \\
\hline & Volume management & Binary \\
\hline & Volume measurement & Binary \\
\hline & Drains & Binary \\
\hline \multirow[t]{4}{*}{ Soil and fertilizer } & Sampling of soil analysis & Binary \\
\hline & Interpretation of soil analysis & Binary \\
\hline & Planning time and rate of fertilization & Binary \\
\hline & Management software SIFA & Binary \\
\hline \multirow[t]{4}{*}{ Pest and disease management } & Recognition and monitoring & Binary \\
\hline & Calibration and maintenance spray & Binary \\
\hline & Biological control & Binary \\
\hline & Cultural control & Binary \\
\hline \multirow[t]{5}{*}{ Climate change adaptation } & Selection of planting season & Binary \\
\hline & Selection variety & Binary \\
\hline & Crop physiology & Binary \\
\hline & Strategies to address the effects & Binary \\
\hline & \multicolumn{2}{|l|}{ Transfer methods } \\
\hline Frequency of training & 1: weekly; 2: fortnightly; 3: monthly; 4: quarterly & Category \\
\hline Day preferred & 1: Monday; 2: Tuesday; 3: Wednesday; 4: Thursday; 5: Friday; 6: Saturday; 7: Sunday & Category \\
\hline Prior notification & 1: 3 days; $2: 5$ days; 3 : one week; 4 : two weeks & Category \\
\hline Types of invitation & 1: email; 2: post mail; 3: fax; 4: phone; 5: personal contact & Category \\
\hline Type of training & 1: talks; 2: conference; 3: workshop; 4: field day; 5: technical tour & Category \\
\hline Type of promotion & 1: radio; 2: social network; 3: parade; 4: flyer & Category \\
\hline
\end{tabular}

where $\mathrm{Y}_{\mathrm{i}}(\mathrm{i}=1,2, \ldots, \mathrm{p})$ is each component score obtained

Table 1. Types of technologies and transfer methods to be included for farmers' preference 
from PCA; $X_{j}(j=1,2, \ldots, n)$ is independent variables or predictors to be included in analysis; $\beta_{\mathrm{ij}}(\mathrm{i}=1,2, \ldots, \mathrm{p}$; $\mathrm{j}=1,2, \ldots, \mathrm{n})$ is correlation coefficient to be estimated; $\varepsilon_{\mathrm{i}}$ $(\mathrm{i}=1,2, \ldots, \mathrm{p})$ is a random error.

\section{Variables description}

Table 1 showed the list of farming technologies and training methods that we included and asked farmers to select based on their preference. All technologies were categorized as calibration technology, irrigation technology, soil and fertilizer, pest and disease management, and climate changes countermeasure, which were proposed by Fedearroz (National Federation of Rice Farmers) of Colombia, who is working for the improvement of rice production in Colombia. Fedearroz has done many research activities to improve below technologies in order to increase production efficiency of rice. After farmers selected their preference of technologies, farmers were asked to choose the appropriated training methods for them. We included the frequency of training, preferred day, prior notification of training, types of invitation, types of training, and types of promotion the events.

Table 2 presented the variables that we used in multivariate regression analysis. We included gender, education, and age of the farmers as individual characteristics; and production land, dummy own land, frequency of irrigation, availability of reservoir, and water capacity as farm characteristics. Finally, we also included farmers' perception of agronomic issues in regression analysis. It includes weed issue, insect issue, disease issue, soil issue, and water issue. Farmers were asked to rank each issue using 5 likert scale range from 1: no important to 5: very important.

\section{RESULTS AND DISCUSSION}

\section{Descriptive result}

This section we show the descriptive results of the study. For farmers' characteristics, most of rice farmers in Ibague are male (94.3\%) with higher educational level, $60 \%$ of farmers graduated from university. Their age are centered between 41-60years (77.1\%). These characteristics indicated the high potential in introducing new and modern technologies to them.

For farm characteristics, only 39 (55.7\%) farmers have their own land and 35 (50\%) have rented farmland from the others. Average production land of farmers is about 175 hectares. Only $54.3 \%$ of farms have reservoir to store water, and $72.9 \%$ of farm has little water capacity. It showed that farmers are large commercial farmers, but they face the water issue for their rice farming.

Farmers perceived that water issue is the most importance, followed by weed, disease, soil and insect respectively. As shown in farm characteristics, farmers lack access to water, and weed will grow faster in the field that lack of water.

\section{Demands for farming technologies and transfer methods}

This section presents farmers' demands of rice farming technologies (Fig. 1). Results show that farmers preferred the calibration and operation of seeder (57.1\%) and laser land leveling (37.1\%) as the highest among other calibration technologies, because farmers wanted to reduce input cost, especially seeds, at the time of sowing, and they needed a good land preparation to reduce water consumption since water is the main issue for their farming. For irrigation technologies, farmers

Table 2. Farmers' characteristics and perception of agronomic issues

\begin{tabular}{|c|c|c|}
\hline Variables & Definition & Unit \\
\hline \multicolumn{3}{|c|}{ Individual' characteristics } \\
\hline Gender & 1: male; 0: female & Binary \\
\hline Education & 1: primary school; 2: basic education; 3 : secondary school; and 4: university graduated & Category \\
\hline Age & 1: 20-40; 2: 41-60; and 3: more than 60 & Category \\
\hline \multicolumn{3}{|c|}{ Farm characteristics } \\
\hline Owned land & Total rice field farmer own & Hectares \\
\hline Rented land & Total rice field farmer rented for rice production & Hectares \\
\hline Production land & Both owned and rented rice field in rice production & Hectares \\
\hline Dummy own land & 1: if farmer has own land; 0: otherwise & Binary \\
\hline Frequency of irrigation & Number of times farmer irrigated their farm & Number \\
\hline Availability of reservoir & 1: if farmer has reservoir; 0: otherwise & Binary \\
\hline Water capacity & $1: 0-25.000 \mathrm{~m}^{3} ; 2:>25.000-50.000 \mathrm{~m}^{3} ; 3:>50.000-100.000 \mathrm{~m}^{3} ; 4:>100.000 \mathrm{~m}^{3}$ & Category \\
\hline \multicolumn{3}{|c|}{ Perception of agronomic issues } \\
\hline Weed issue & 1: no important; 2: little important; 3: moderately important; 4: important; 5: very important & Order \\
\hline Insect issue & 1: no important; 2: little important; 3: moderately important; 4: important; 5 : very important & Order \\
\hline Disease issue & 1: no important; 2: little important; 3: moderately important; 4: important; 5 : very important & Order \\
\hline Soil issue & 1: no important; 2: little important; 3 : moderately important; 4 : important; 5 : very important & Order \\
\hline Water issue & 1: no important; 2 : little important; 3 : moderately important; 4: important; 5 : very important & Order \\
\hline
\end{tabular}


Table 3. Descriptive statistics of farmers' characteristics and perception of agronomic issues

\begin{tabular}{|c|c|c|c|c|}
\hline Variables & Unit & Obs & Mean & Std. Dev. \\
\hline Gender & Proportion & 70 & 0.943 & 0.234 \\
\hline \multicolumn{5}{|l|}{ Education } \\
\hline Primary & Proportion & 70 & 0.157 & 0.367 \\
\hline Basic & Proportion & 70 & 0.071 & 0.259 \\
\hline Secondary & Proportion & 70 & 0.171 & 0.380 \\
\hline University & Proportion & 70 & 0.600 & 0.493 \\
\hline \multicolumn{5}{|l|}{ Age } \\
\hline $20-40$ & Proportion & 70 & 0.086 & 0.282 \\
\hline $41-60$ & Proportion & 70 & 0.771 & 0.423 \\
\hline$>60$ & Proportion & 70 & 0.143 & 0.352 \\
\hline Owned land & Hectares & 39 & 197.256 & 256.236 \\
\hline Rented land & Hectares & 35 & 130.314 & 149.758 \\
\hline Production land & Hectares & 70 & 175.057 & 216.208 \\
\hline Dummy own land & Proportion & 70 & 0.557 & 0.500 \\
\hline Frequency of irrigation & Number & 70 & 2.857 & 0.839 \\
\hline Availability of reservoir & Proportion & 70 & 0.543 & 0.502 \\
\hline \multicolumn{5}{|l|}{ Water capacity } \\
\hline $0-25.000 \mathrm{~m}^{3}$ & Proportion & 70 & 0.729 & 0.448 \\
\hline $25.000-50.000 \mathrm{~m}^{3}$ & Proportion & 70 & 0.129 & 0.337 \\
\hline $50.000-100.000 \mathrm{~m}^{3}$ & Proportion & 70 & 0.086 & 0.282 \\
\hline$>100.000 \mathrm{~m}^{3}$ & Proportion & 70 & 0.057 & 0.234 \\
\hline \multicolumn{5}{|c|}{ Perception of agronomic issues } \\
\hline weed issue & Score & 70 & 4.343 & 0.931 \\
\hline insect issue & Score & 70 & 3.257 & 1.003 \\
\hline disease issue & Score & 70 & 3.886 & 0.925 \\
\hline soil issue & Score & 70 & 3.671 & 0.896 \\
\hline water issue & Score & 70 & 4.857 & 0.572 \\
\hline
\end{tabular}

Source: Survey 2015

require more efficient use of water on their farms because water in Ibague is very limited. As a result, farmers have the high interest in learning about volume management and measurement of water with $65.7 \%$ and $31.4 \%$ respectively. The interpretation of soil analysis is the basis tool for developing a plan for nutrition and fertilization in according to the rice variety to maximize the yield. In addition, the importance of having knowledge about farm soil is ideal to manage and apply further nutrients to the farm. Hence, results indicate that farmers preferred soil analysis interpretation with $54.3 \%$ and fertilization planning with $25.7 \%$ as their main demand for soil and fertilizer management. To control pest and diseases, farmers show high interest in biological control (41.4\%) instead of chemical spraying because they have experiented about the issues of chemical spraying. Since farmers in Ibague have higher knowledge and education level, they sometime are able to give support to the work of the specialists and provide prompt solution to some problems. Hence, they also show interest in recognition and monitoring of pest as high as 37.1\%. To cope with the climate changes, farmers require more information on proper selection of the variety (77.1\%) and strategies to address the effect (20\%) of climate changes because their varieties present year-to-year fluctuation in production arrected by climate uncertainty.

Farmers' preferences of training methods are shown in Figure 2. The results indicate that $64.3 \%$ of farmers preferred a monthly training. They are not able to attend the training more frequent duo to their farming work. $61.4 \%$ of farmers want to attend the events of technology transfer on Friday since it is the day with less workload of farm activities. The appropriate time to send the invitation about technology transfer events must be between 3 to 7 days before the events to allow them to arrange their time for attending the events. Farmers prefer to receive the invitation via email (50\%) considering that sometimes farmers are not available for phone call and face-to-face contact. $47.1 \%$ of farmers also considered phone call is suitable for them to get notification of invitation because it is convenient to explain the event and able to contact them at anytime. The results point out that $62.9 \%$ of farmers want to attend field day for the technology transfer since it is possible 


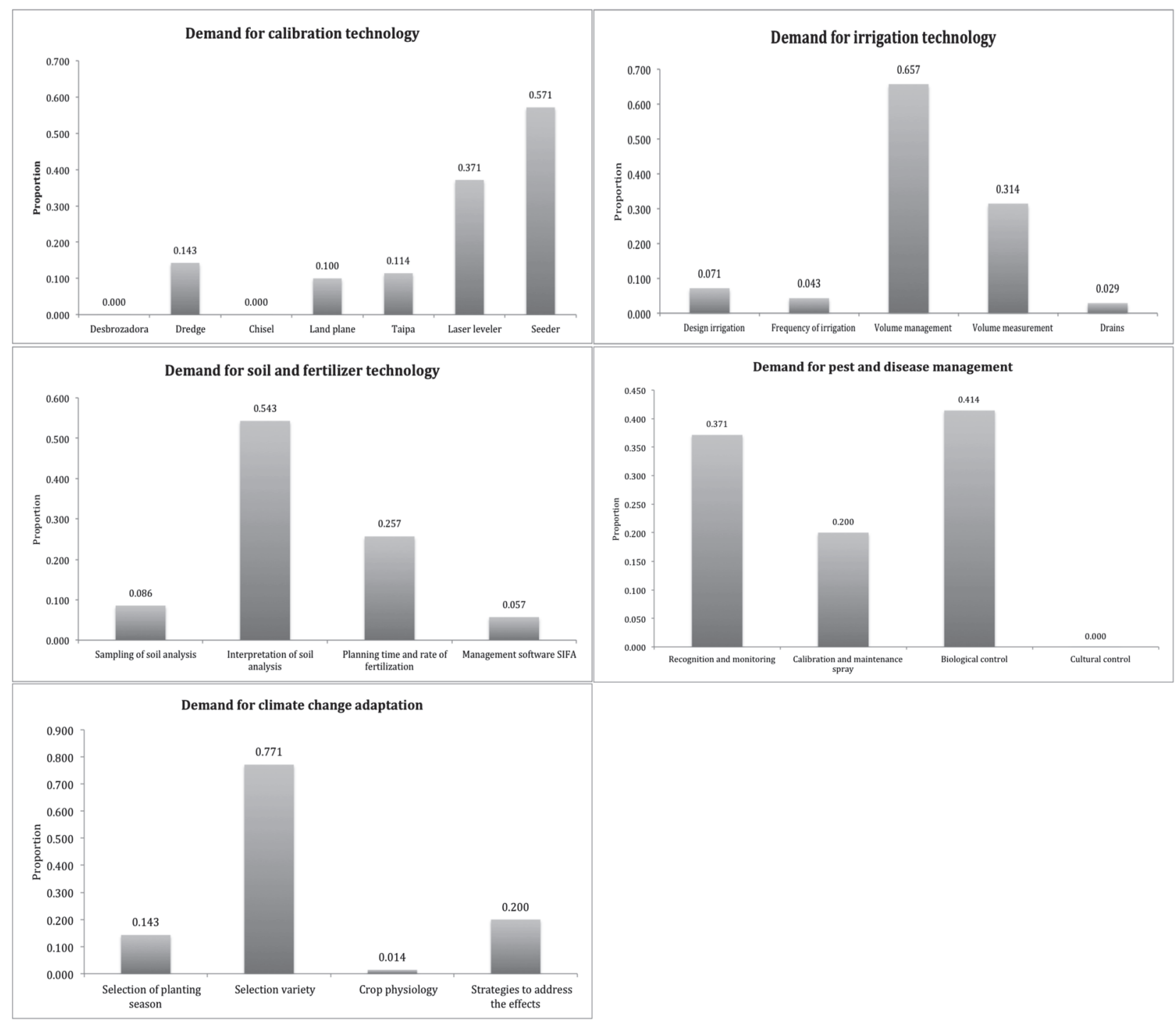

Fig. 1. Farmers' demand for farming technologies.

for them to learn new technology from other farmers and they can practice simultaneously. Finally, $58.6 \%$ of farmers believe that social networks are crucial tools to promote the new technology since farmers usually access to the social networks for updated information through smartphone or computer. Radio is a medium tool, which $27.1 \%$ of farmers consider as an effective way to get more people to the events.

\section{Determinants of demand for farming technologies}

This section presents the relationship of farmers' characteristics and perception with demands for farming technologies. To obtain the correlation matrix, we employed tetrachoric correlation proposed by Edwards and Edwards (1984). Then, we performed PCA (Jackson, 2003) to reduce the dimension of technologies variables. We included only important technologies that required by farmers, such as dredge, land plane, Taipa, laser leveler, seeder, design irrigation, volume management, volume measurement, sampling of soil analysis, interpretation of soil analysis, planning time and rate of fertilization, pest recognition and monitoring, calibration and maintenance spray, biological pest control, selection of planting season, selection variety, and strategies to address the effects of climate changes.

The PCA yielded 6 components, and each component are named as follow: ICT related technology (loading variables: volume measurement, interpretation of soil analysis, planning time and rate of fertilization, and calibration and maintenance spray), physical and biological pest control (loading variables: dredge, land Plane, pest recognition and monitoring, and biological control), soil preparation and fertilization (loading variables: laser leveler, sampling of soil analysis, planning time and rate of fertilization, and strategies to address the effects), crop and irrigation planning (loading variables: Taipa, design irrigation, selection of planting season, and selection variety), water shortage management (loading variables: Taipa, and volume management), and sowing technology (loading variables: land plane, and seeder). Table 4 shows the loading score of each technology with each component. We decided to keep the variables that have loading score more than 0.3 in each component, and perform the multivariate regression.

The results of multivariate regression are shown in 


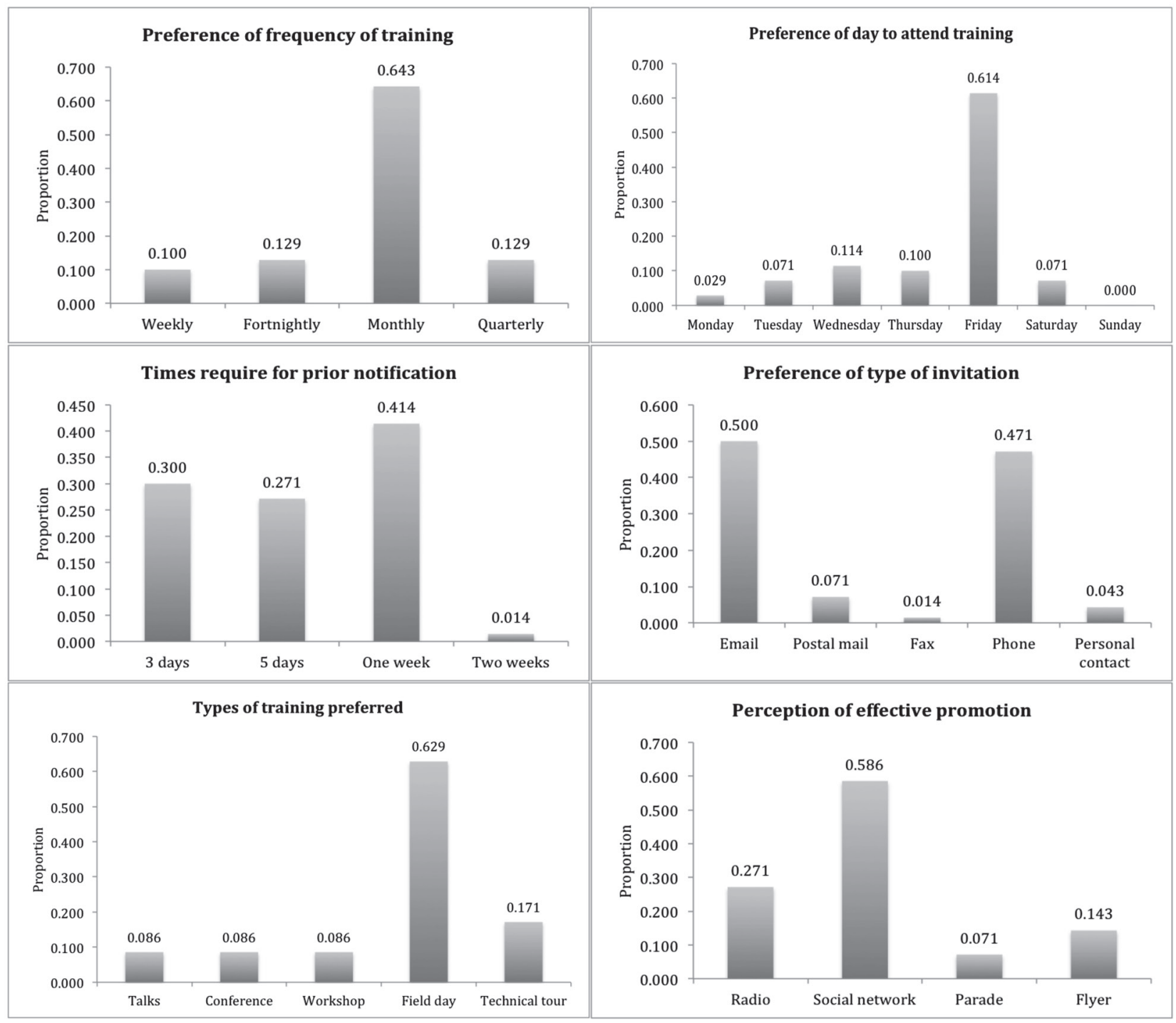

Fig. 2. Farmers' preference of transfer methods.

Table 4. Component loading score of PCA

\begin{tabular}{|c|c|c|c|c|c|c|}
\hline \multirow{2}{*}{ Variable } & \multicolumn{6}{|c|}{ Component } \\
\hline & 1 & 2 & 3 & 4 & 5 & 6 \\
\hline Dredge & & 0.4351 & & & & \\
\hline Land plane & & 0.4116 & & & & 0.4531 \\
\hline Taipa & & & & 0.3511 & -0.3018 & \\
\hline Laser leveler & & & -0.3399 & & & \\
\hline Seeder & & & & & & 0.7170 \\
\hline Design irrigation & & & & 0.5387 & & \\
\hline Volume management & & & & & 0.6585 & \\
\hline Volume measurement & 0.3549 & & & & & \\
\hline Sampling of soil analysis & & & 0.6348 & & & \\
\hline Interpretation of soil analysis & 0.4990 & & & & & \\
\hline Planning time and rate of fertilization & -0.3753 & & -0.4419 & & & \\
\hline Recognition and monitoring & & 0.4412 & & & & \\
\hline Calibration and maintenance spray & -0.5301 & & & & & \\
\hline Biological control & & -0.5522 & & & & \\
\hline Selection of planting season & & & & 0.4771 & & \\
\hline Selection variety & & & & 0.4397 & & \\
\hline Strategies to address the effects & & & 0.3281 & & & \\
\hline
\end{tabular}

Note: Only over 0.3 of loading scores were kept 
Table 5. It suggests that male farmers are less likely to demand for crop and irrigation planning. Male farmers are better in farm activities, and have higher access to resources and information (Asfaw \& Admassie, 2004; Odendo et al., 2009). Hence, they don't need this technology.

Compared to primary education, farmers with basic education are more likely to demand for crop and irrigation planning, and water shortage management, but less likely to demand for soil preparation and fertilization. Farmers with secondary education are less likely to demand for soil preparation and fertilization, but more likely to demand for water shortage management.
Farmers with higher education are more likely to demand for ICT related technology, crop and irrigation planning, and water shortage management. They are less likely to demand for physical and biological pest control, and soil preparation and fertilization, however, if we look at the sign of biological control in Table 4, it shows that higher education farmers are more likely to demand for this technology. With higher education level, farmers are keen to learn, and having ability to learn modern technology much faster (Feder et al., 1985). Hence, they show higher interest in modern and cost efficient technologies including ICT related technologies, biological pest control, farm planning, and water short-

Table 5. Multivariate regression of component score and farmers' characteristics

\begin{tabular}{|c|c|c|c|c|c|c|}
\hline \multirow{2}{*}{ Variable } & IRT & PBP & $\mathrm{SPF}$ & CIP & WSM & ST \\
\hline & Coef. & Coef. & Coef. & Coef. & Coef. & Coef. \\
\hline Gender & $\begin{array}{l}-0.270 \\
(0.374)\end{array}$ & $\begin{array}{l}-0.048 \\
(0.274)\end{array}$ & $\begin{array}{r}0.155 \\
(0.256)\end{array}$ & $\begin{array}{r}-\mathbf{0 . 5 6 0} * * \\
(0.217)\end{array}$ & $\begin{array}{r}0.381 \\
(0.323)\end{array}$ & $\begin{array}{l}-0.372 \\
(0.310)\end{array}$ \\
\hline \multicolumn{7}{|l|}{ Education } \\
\hline Basic & $\begin{array}{r}0.298 \\
(0.420)\end{array}$ & $\begin{array}{r}0.342 \\
(0.307)\end{array}$ & $\begin{array}{r}-\mathbf{0 . 6 6 8} * * \\
(0.287)\end{array}$ & $\begin{array}{r}\mathbf{0 . 6 4 2} * * \\
(0.244)\end{array}$ & $\begin{array}{r}\mathbf{0 . 7 8 6}^{* * *} \\
(0.362)\end{array}$ & $\begin{array}{l}-0.113 \\
(0.348)\end{array}$ \\
\hline Secondary & $\begin{array}{r}0.331 \\
(0.297)\end{array}$ & $\begin{array}{l}-0.274 \\
(0.217)\end{array}$ & $\begin{array}{r}-\mathbf{0 . 4 4 6}^{* * *} \\
(0.203)\end{array}$ & $\begin{array}{c}-0.066 \\
(0.172)\end{array}$ & $\begin{array}{l}\mathbf{0 . 4 8 1} * \\
(0.256)\end{array}$ & $\begin{array}{r}0.135 \\
(0.246)\end{array}$ \\
\hline University & $\begin{array}{r}\mathbf{0 . 5 2 5} * * \\
(0.257)\end{array}$ & $\begin{array}{r}-\mathbf{0 . 4 8 0} * * \\
(0.188)\end{array}$ & $\begin{array}{r}-\mathbf{0 . 6 1 5} * * * \\
(0.175)\end{array}$ & $\begin{array}{r}\mathbf{0 . 3 1 1}^{* * *} \\
(0.149)\end{array}$ & $\begin{array}{r}\mathbf{0 . 4 7 9} * * \\
(0.222)\end{array}$ & $\begin{array}{r}0.094 \\
(0.213)\end{array}$ \\
\hline \multicolumn{7}{|l|}{ Age } \\
\hline $41-60$ & $\begin{array}{l}-0.087 \\
(0.341)\end{array}$ & $\begin{array}{l}-0.215 \\
(0.249)\end{array}$ & $\begin{array}{r}-\mathbf{0 . 4 8 6}^{* * *} \\
(0.233)\end{array}$ & $\begin{array}{r}0.127 \\
(0.198)\end{array}$ & $\begin{array}{r}0.234 \\
(0.294)\end{array}$ & $\begin{array}{r}0.084 \\
(0.282)\end{array}$ \\
\hline$>60$ & $\begin{array}{l}-0.559 \\
(0.411)\end{array}$ & $\begin{array}{r}-\mathbf{0 . 5 0 8} \\
(0.301)\end{array}$ & $\begin{array}{r}-0.355 \\
(0.281)\end{array}$ & $\begin{array}{l}-0.048 \\
(0.239)\end{array}$ & $\begin{array}{r}0.127 \\
(0.355)\end{array}$ & $\begin{array}{r}0.020 \\
(0.341)\end{array}$ \\
\hline Production land & $\begin{array}{r}0.000 \\
(0.001)\end{array}$ & $\begin{array}{r}0.000 \\
(0.000)\end{array}$ & $\begin{array}{r}0.000 \\
(0.000)\end{array}$ & $\begin{array}{r}0.000 \\
(0.000)\end{array}$ & $\begin{array}{r}0.000 \\
(0.000)\end{array}$ & $\begin{array}{r}0.001 \\
(0.000)\end{array}$ \\
\hline Dummy own land & $\begin{array}{l}-0.045 \\
(0.187)\end{array}$ & $\begin{array}{r}-\mathbf{0 . 2 3 3} * \\
(0.137)\end{array}$ & $\begin{array}{r}0.122 \\
(0.128)\end{array}$ & $\begin{array}{r}0.146 \\
(0.109)\end{array}$ & $\begin{array}{l}-0.158 \\
(0.161)\end{array}$ & $\begin{array}{r}-0.009 \\
(0.155)\end{array}$ \\
\hline Frequency of irrigation & $\begin{array}{r}0.109 \\
(0.105)\end{array}$ & $\begin{array}{r}-0.080 \\
(0.077)\end{array}$ & $\begin{array}{l}-0.018 \\
(0.072)\end{array}$ & $\begin{array}{r}0.034 \\
(0.061)\end{array}$ & $\begin{array}{r}0.062 \\
(0.091)\end{array}$ & $\begin{array}{r}-0.015 \\
(0.087)\end{array}$ \\
\hline Availability of reservoir & $\begin{array}{r}\mathbf{0 . 5 3 1} * * \\
(0.220)\end{array}$ & $\begin{array}{l}-0.263 \\
(0.161)\end{array}$ & $\begin{array}{r}\mathbf{0 . 4 1 4}^{* * * *} \\
(0.150)\end{array}$ & $\begin{array}{l}-0.043 \\
(0.128)\end{array}$ & $\begin{array}{l}-0.011 \\
(0.190)\end{array}$ & $\begin{array}{r}0.003 \\
(0.182)\end{array}$ \\
\hline \multicolumn{7}{|l|}{ Water capacity } \\
\hline $25.000-50.000 \mathrm{~m}^{3}$ & $\begin{array}{l}-0.152 \\
(0.308)\end{array}$ & $\begin{array}{r}0.326 \\
(0.225)\end{array}$ & $\begin{array}{l}-0.246 \\
(0.211)\end{array}$ & $\begin{array}{l}-0.021 \\
(0.179)\end{array}$ & $\begin{array}{l}-0.372 \\
(0.266)\end{array}$ & $\begin{array}{l}-0.078 \\
(0.255)\end{array}$ \\
\hline $50.000-100.000 \mathrm{~m}^{3}$ & $\begin{array}{l}-0.251 \\
(0.392)\end{array}$ & $\begin{array}{r}0.241 \\
(0.286)\end{array}$ & $\begin{array}{l}-0.051 \\
(0.268)\end{array}$ & $\begin{array}{r}0.095 \\
(0.228)\end{array}$ & $\begin{array}{r}0.027 \\
(0.338)\end{array}$ & $\begin{array}{r}0.088 \\
(0.324)\end{array}$ \\
\hline$>100.000 \mathrm{~m}^{3}$ & $\begin{array}{r}-\mathbf{0 . 9 5 5} * * \\
(0.461)\end{array}$ & $\begin{array}{r}0.475 \\
(0.337)\end{array}$ & $\begin{array}{l}-0.482 \\
(0.315)\end{array}$ & $\begin{array}{r}0.148 \\
(0.268)\end{array}$ & $\begin{array}{l}-0.252 \\
(0.398)\end{array}$ & $\begin{array}{r}-0.303 \\
(0.382)\end{array}$ \\
\hline Weed & $\begin{array}{l}-0.205 \\
(0.124)\end{array}$ & $\begin{array}{r}-\mathbf{0 . 3 6 8} \text { **** } \\
(0.091)\end{array}$ & $\begin{array}{l}-0.072 \\
(0.085)\end{array}$ & $\begin{array}{r}0.089 \\
(0.072)\end{array}$ & $\begin{array}{r}0.063 \\
(0.107)\end{array}$ & $\begin{array}{r}0.065 \\
(0.103)\end{array}$ \\
\hline Insect & $\begin{array}{r}0.024 \\
(0.134)\end{array}$ & $\begin{array}{r}\mathbf{0 . 6 3 1} * * * \\
(0.098)\end{array}$ & $\begin{array}{r}0.141 \\
(0.091)\end{array}$ & $\begin{array}{r}-\mathbf{0 . 2 1 6} * * * \\
(0.078)\end{array}$ & $\begin{array}{r}0.139 \\
(0.115)\end{array}$ & $\begin{array}{r}-\mathbf{0 . 2 0 0} \% \\
(0.111)\end{array}$ \\
\hline Disease & $\begin{array}{l}-0.043 \\
(0.122)\end{array}$ & $\begin{array}{r}-\mathbf{0 . 3 2 1} \text { **** } \\
(0.089)\end{array}$ & $\begin{array}{r}-\mathbf{0 . 3 0 3} * * * * \\
(0.084)\end{array}$ & $\begin{array}{l}\mathbf{0 . 1 3 6}^{*} \\
(0.071)\end{array}$ & $\begin{array}{r}0.053 \\
(0.106)\end{array}$ & $\begin{array}{r}\mathbf{0 . 2 1 3} * * \\
(0.101)\end{array}$ \\
\hline Soil & $\begin{array}{r}-\mathbf{0 . 1 8 9} * \\
(0.104)\end{array}$ & $\begin{array}{r}-0.066 \\
(0.076)\end{array}$ & $\begin{array}{l}-0.007 \\
(0.071)\end{array}$ & $\begin{array}{r}-\mathbf{0 . 1 1 6}^{*} \\
(0.060)\end{array}$ & $\begin{array}{l}-0.039 \\
(0.090)\end{array}$ & $\begin{array}{r}-0.025 \\
(0.086)\end{array}$ \\
\hline Water & $\begin{array}{r}0.133 \\
(0.153)\end{array}$ & $\begin{array}{r}-\mathbf{0 . 3 2 6} \text { **** } \\
(0.112)\end{array}$ & $\begin{array}{r}0.086 \\
(0.105)\end{array}$ & $\begin{array}{r}-\mathbf{0 . 2 2 3} * * \\
(0.089)\end{array}$ & $\begin{array}{r}0.051 \\
(0.132)\end{array}$ & $\begin{array}{l}-0.053 \\
(0.127)\end{array}$ \\
\hline Constant & $\begin{array}{r}1.061 \\
(1.187)\end{array}$ & $\begin{array}{r}\mathbf{3 . 5 6 8}^{*} * * \\
(0.868)\end{array}$ & $\begin{array}{r}0.915 \\
(0.811)\end{array}$ & $\begin{array}{r}\mathbf{1 . 8 5 7} * * \\
(0.690)\end{array}$ & $\begin{array}{l}-1.377 \\
(1.025)\end{array}$ & $\begin{array}{r}0.674 \\
(0.983)\end{array}$ \\
\hline $\mathrm{R}^{2}$ & 0.350 & 0.601 & 0.473 & 0.522 & 0.351 & 0.279 \\
\hline
\end{tabular}

Source: Survey 2015

Note: *,**, and *** are significant level at $10 \%, 5 \%$, and $1 \%$ respectively; number in parentheses is standard error; IRT is ICT related technologies, PBP is physical and biological pest control, SPF is soil preparation and fertilization, CIP is crop and irrigation planning, WSM is water shortage management, ST is sowing technology. 
age management. However, higher educated farmers have lower interest in technologies such as physical pest control, soil sampling and analysis because they have already had some skills and knowledge about these technologies.

Middle age farmers are less likely to demand for soil preparation and fertilization, and older age farmers are less likely to demand for physical and biological pest control. Older farmers didn't want to learn intensive labor technology, and are risk averse, so they are unlikely to adopt new technologies (Khanna, 2001). Moreover, they have more experiences in farming leading them lack of interest in learning new technology. However, older farmers showed higher interest in biological pest control, laser land leveler, and fertilization planning if we look in detail of technologies in each component loading.

Farmers who have their own land are less likely to demand for physical pest control, but more demand for biological control since they have knowledge about the consequences of chemical spraying. Farmers with reservoir availability are more likely to demand for ICTrelated technology, and soil preparation and fertilization. While higher water capacity influences farmers to be less likely to demand for ICT-related technology. With water, farmers are interested in ICT related technology to manage irrigation and farm. On the other hand, if they have excessive water, farmers don't need higher technology to manage their water because it is not the main issue. When farmers could deal with water issue, they also need technology such as soil sampling and strategies to cope with climate changes.

Regarding to agronomic issues, farmers show less demand for ICT related technology when they perceived soil issue is more important because this technology is not able to deal with soil issue. When weed, disease and water are regarded as important issues, farmers are less likely to demand for physical pest control but prefer biological control. However, when insect is perceived as important, farmers less demand for biological control because biological method is hard to control for insect when it outbreaks. If disease becomes more important, farmers need a good land preparation and accurate application of fertilizer. For crop and irrigation planning, farmers are less likely to demand this technology when insect, soil, and water are perceived as of importance. On the other hand, farmers demand for crop and irrigation planning when disease is perceived as more importance. With sowing technology, disease can be minimized, but insect is hard to control. Hence, farmers show high demand when disease is perceived as importance, but low demand when insect is more important.

\section{CONCLUSION AND RECOMMENDATION}

To address the issue of production cost and water shortage, farmers show high interest in sowing calibration and laser land leveling with the irrigation technology such as volume management and measurement. Farmers also prefer to soil analysis interpretation and fertilization planning as their main demand for soil and fertilizer management to improve the quality of their soil. Farmers are interested in biological pest control and pest recognition and monitoring to avoid excessive use of chemical spraying and to minimize their cost. To cope with the climate changes, farmers require more information on proper selection of the variety. The results indicated that farmers prefer to field day for technology transfer that they could attend once a month on Friday. They require prior notification of invitation by email and phone call between 3 to 7 days before the events to allow them to arrange their time. Farmers believe that social network and radio are the crucial tools to promote the technology transfer event.

The results of multivariate regression suggest that male farmer is less likely to demand for crop and irrigation planning. Farmers with basic education and higher level of education show higher interest in modern technologies to address the water issue, but less likely to demand for physical and biological pest control, and soil preparation and fertilization. Middle and older age farmers are more likely to demand for crop planting and irrigation management technology, but they show lower interest in learning higher technology in rice farming. Farmers who own their land are more interested in crop and irrigation planning, and soil fertilization that could help maintain soil nutrition in their farm. Farmers with reseroir availability are more likely to demand for ICT related technology, and soil preparation and fertilization, while higher water capacity influence farmers to be interested in physical and biological pest control, and crop and irrigation planning. Regarding to agronomic issues, farmers tend to demand for technologies that could help minimize relative issues.

Based on the result, we would recommend to researchers to develop the technology that could help minimizing production cost, particularly seed cost. Since water issue is the most important problem, the specific water shortage management technology should be innovated. All related institutions should organize a field day every month on Friday by promoting in social networks and other means of communications. Farmers prefer to technologies based upon their characteristics and relative issues, hence, all technologies should be farmers based innovated technology, which researchers and farmers jointly innovated.

\section{ACKNOWLEDGEMENT}

This research is supported by JST (Japan Science and Technology Agency) SATREPS Project. The authors would like to thank Dr. Dongpo LI, Kyushu University, for his useful comments and kind support in preparing this paper.

\section{REFERENCES}

Asfaw, A. and A. Admassie 2004 The role of education on the adoption of chemical fertilizer under different socioeconomic environments in Ethiopia. Agricultural Economics, $\mathbf{3 0}(3)$ : $215-228$ 
Appendix 1. Correlation matrix of Tetrachoric correlation

\begin{tabular}{|c|c|c|c|c|c|c|c|c|c|c|c|c|c|c|c|c|c|c|c|c|c|}
\hline Variables & 1 & 2 & 3 & 4 & 5 & 6 & 7 & 8 & 9 & 10 & 11 & 12 & 13 & 14 & 15 & 16 & 17 & 18 & 19 & 20 & 21 \\
\hline 1. Dredge & 1.00 & & & & & & & & & & & & & & & & & & & & \\
\hline 2. Land plane & 0.52 & 1.00 & & & & & & & & & & & & & & & & & & & \\
\hline 3. Taipa & 0.46 & 0.77 & 1.00 & & & & & & & & & & & & & & & & & & \\
\hline 4. Laser leveler & -0.30 & $-0.13-$ & -0.20 & 1.00 & & & & & & & & & & & & & & & & & \\
\hline 5. Seeder & -0.42 & $0.45-$ & $-0.11-$ & -0.27 & 1.00 & & & & & & & & & & & & & & & & \\
\hline 6. Design irrigation & 0.12 & 0.77 & 0.52 & 0.04 & 0.04 & 1.00 & & & & & & & & & & & & & & & \\
\hline 7. Frequency of irrigation* & $-1.00-$ & $-1.00-$ & -1.00 & 1.00 & $1.00-$ & -1.00 & 1.00 & & & & & & & & & & & & & & \\
\hline 8. Volume management & 0.08 & $-0.13-$ & $-0.41-$ & -0.40 & $0.26-$ & $-0.34-$ & -1.00 & 1.00 & & & & & & & & & & & & & \\
\hline 9. Volume measurement & -0.44 & $-0.05-$ & -0.11 & 0.57 & $0.45-$ & -0.18 & $1.00-$ & -0.45 & 1.00 & & & & & & & & & & & & \\
\hline 10. Drains* & $-1.00-$ & $-1.00-$ & -1.00 & $1.00-$ & $-1.00-$ & $-1.00-$ & $-1.00-1$ & $-1.00-1$ & 1.00 & 1.00 & & & & & & & & & & & \\
\hline 11. Sampling of soil analysis & 0.59 & 0.18 & 0.13 & $-1.00-$ & -0.10 & $0.29-$ & -1.00 & $0.29-$ & $-0.25-$ & -1.00 & 1.00 & & & & & & & & & & \\
\hline $\begin{array}{l}\text { 12. Interpretation of soil } \\
\text { analysis }\end{array}$ & -0.07 & $-0.16-$ & -0.06 & 0.18 & $0.21-$ & -0.19 & 1.00 & 0.29 & $0.41-$ & $-1.00-$ & -0.29 & 1.00 & & & & & & & & & \\
\hline $\begin{array}{l}\text { 13. Planning time and rate of } \\
\text { fertilization }\end{array}$ & -0.36 & $0.05-$ & $-0.27-$ & $-0.08-$ & $-0.14-$ & $-0.10-$ & $-1.00-$ & $-0.10-1$ & -0.21 & $1.00-$ & $-1.00-$ & -0.87 & 1.00 & & & & & & & & \\
\hline $\begin{array}{l}\text { 14. Management software } \\
\text { SIFA* }\end{array}$ & $-1.00-$ & $-1.00-$ & -1.00 & $0.16-$ & -0.09 & $0.73-$ & $-1.00-$ & $-0.20-1$ & $1.00-1$ & -1.00 & $0.37-1$ & $-1.00-$ & -1.00 & 1.00 & & & & & & & \\
\hline $\begin{array}{l}\text { 15. Recognition and } \\
\text { monitoring }\end{array}$ & 0.36 & 0.08 & $0.01-$ & $-0.37-$ & $-0.45-$ & $-0.26-$ & -1.00 & $0.30-1$ & $-0.34-$ & $-1.00-$ & -0.06 & $0.27-$ & $-0.32-$ & -0.17 & 1.00 & & & & & & \\
\hline $\begin{array}{l}\text { 16. Calibration and } \\
\text { maintenance spray }\end{array}$ & -0.26 & $0.16-$ & $-0.17-$ & -0.17 & 0.00 & $0.31-$ & -1.00 & $0.26-$ & -1.00 & $1.00-$ & $-0.07-$ & -0.68 & 0.77 & $0.08-$ & -0.46 & 1.00 & & & & & \\
\hline 17. Biological control & -1.00 & $-0.43-$ & -0.06 & 0.31 & 0.49 & 0.24 & $1.00-$ & -0.20 & $0.64-$ & $-1.00-$ & -0.12 & $0.12-$ & -0.40 & $0.42-$ & $-0.80-($ & -0.38 & 1.00 & & & & \\
\hline $\begin{array}{l}\text { 18. Selection of planting } \\
\text { season }\end{array}$ & -0.13 & 0.30 & 0.46 & 0.50 & 0.58 & $0.44-$ & -1.00 & 0.26 & $0.71-$ & -1.00 & 0.06 & $0.42-$ & $-0.36-$ & $-1.00-$ & $-0.30-\mathrm{c}$ & -0.26 & 0.59 & 1.00 & & & \\
\hline 19. Selection variety & -0.32 & $-0.33-$ & -0.26 & 0.25 & 0.36 & 1.00 & 1.00 & 0.31 & 0.28 & 1.00 & -0.78 & 0.43 & $0.53-1$ & $-0.37-$ & -0.25 & 0.22 & 0.33 & 1.00 & 1.00 & & \\
\hline 20. Crop physiology* & -1.00 & $1.00-$ & $-1.00-$ & $-1.00-$ & $-1.00-$ & $-1.00-$ & -1.001 & $1.00-1$ & $1.00-1$ & $-1.00-$ & $-1.00-1$ & -1.00 & $1.00-1$ & 1.00 & $1.00-1$ & $1.00-1$ & -1.00-1. & -1.00-1. & 1.00 & 1.00 & \\
\hline $\begin{array}{l}\text { 21. Strategies to address } \\
\text { the effects }\end{array}$ & 0.21 & 0.38 & $0.10-$ & -0.17 & 0.13 & 0.31 & $0.57-$ & -0.16 & $0.35-$ & -1.00 & 0.81 & $0.18-$ & -0.48 & 0.42 & $0.23-0$ & $-0.15-$ & $-0.11-$ & $-0.26-$ & $-0.74-1$ & -1.00 & 1.00 \\
\hline
\end{tabular}

Note: * technologies excluded in PCA

Bellon, R. M. 2001 Participatory research methods for technology evaluation: a manual for scientists working with farmers. Mexico, D.F.: CIMMYT

Durand-Morat, A. 2012 Brief description of the Colombian rice sector [PowerPoint slides]. Retrieved from, http://gmrice.uark. edu/Brief\%20on\%20Colombia\%20and\%20Argentina\%20Rice\%20 Market_ADurand_morat.pdf

Edwards, J. H., and A. W. F. Edwards 1984 Approximating the tetrachoric correlation coefficient. Biometrics, 40: 563

Feder, G., R. E. Just and D. Zilberman 1985 Adoption of agricultural innovations in developing countries: A survey. Economic Development and Cultural Change, 33(2): 255298

Garay, L. J. S., Barberi, F. G. and Cardona, I. L. 2009 Impact of the US-Colombia FTA on the small farm economy in Colombia. Bogota, Oxfam International

Jackson, J. E. 2003 A User's Guide to Principal Components. New York, Wiley

Khanna, M. 2001 Sequential adoption of site-specific technologies and its implications for nitrogen productivity: A double selectivity model. American Journal of Agricultural Economics, 83(1): 35-51

Odendo, M., G. Obare and B. Salasya 2009 Factors responsible for differences in uptake of integrated soil fertility management practices amongst smallholders in western Kenya. African Journal of Agricultural Research, 4(11): 1303-1311
Appendix 2. Eigenvalue of PCA

\begin{tabular}{|c|c|c|c|c|}
\hline Component & Eigenvalue & Difference & Proportion & Cumulative \\
\hline 1 & 3.960 & 0.764 & 0.233 & 0.233 \\
\hline 2 & 3.195 & 0.617 & 0.188 & 0.421 \\
\hline 3 & 2.578 & 0.617 & 0.152 & 0.573 \\
\hline 4 & 1.961 & 0.157 & 0.115 & 0.688 \\
\hline 5 & 1.803 & 0.737 & 0.106 & 0.794 \\
\hline 6 & 1.066 & 0.227 & 0.063 & 0.857 \\
\hline 7 & 0.839 & 0.210 & 0.049 & 0.906 \\
\hline 8 & 0.629 & 0.090 & 0.037 & 0.943 \\
\hline 9 & 0.539 & 0.231 & 0.032 & 0.975 \\
\hline 10 & 0.308 & 0.186 & 0.018 & 0.993 \\
\hline 11 & 0.122 & 0.122 & 0.007 & 1.000 \\
\hline 12 & 0.000 & 0.000 & 0.000 & 1.000 \\
\hline 13 & 0.000 & 0.000 & 0.000 & 1.000 \\
\hline 14 & 0.000 & 0.000 & 0.000 & 1.000 \\
\hline 15 & 0.000 & 0.000 & 0.000 & 1.000 \\
\hline 16 & 0.000 & 0.000 & 0.000 & 1.000 \\
\hline 17 & 0.000 & . & 0.000 & 1.000 \\
\hline
\end{tabular}

Note: We extract 6 components that have eigenvalues larger than 1 , which explain $85.7 \%$ of the variance in our sample. 